\title{
Development of a Laminar Flow Bioreactor by Computational Fluid Dynamics
}

\author{
Meir Israelowitz ${ }^{1 \S}$, Birgit Weyand ${ }^{2 \S}$, Syed Rizvi ${ }^{1}$, Peter M. Vogt ${ }^{2}$, \\ Herbert P. von Schroeder $1,3,4,5 *$

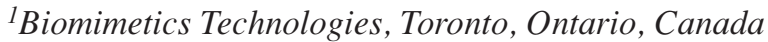 \\ ${ }^{2}$ Department of Plastic, Hand and Reconstructive Surgery, Hannover Medical School, \\ Hannover, Germany \\ ${ }^{3}$ Bone Lab, Faculty of Dentistry, University of Toronto, Toronto, Ontario, Canada \\ ${ }^{4}$ University Hand Program, University Health Network, Toronto, Ontario, Canada \\ ${ }^{5}$ Department of Surgery, University of Toronto, Ontario, Canada
}

Submitted February 2011. Accepted for publication May 2012.

\begin{abstract}
The purpose of this study is to improve the design of a bioreactor for growing bone and other threedimensional tissues using a computational fluid dynamics (CFD) software to simulate flow through a porous scaffold, and to recommend design changes based on the results. Basic requirements for CFD modeling were that the flow in the reactor should be laminar and any flow stagnation should be avoided in order to support cellular growth within the scaffold. We simulated three different designs with different permeability values of the scaffold and tissue. Model simulation addressed flow patterns in combination with pressure distribution within the bioreactor. Pressure build-up and turbulent flow within the reactor was solved by introduction of an integrated bypass system for pressure release. The use of CFD afforded direct feedback to optimize the bioreactor design.
\end{abstract}

Keywords: bioreactor, laminar flow, computer graphic mesh, fluid flow simulations, computational fluid dynamics

\section{INTRODUCTION}

A bioreactor supports a biologically active environment for growing and expanding cells in a culture medium [1]. It can support three-dimensional tissue cultivation and specific cell differentiation by controlled external forces and stresses [2]. However, design limitations have resulted in undesirable fluid-induced shear forces or stagnation of fluid medium causing high mortality of cells and tissues, especially in perfusion bioreactors $[3,4]$.

*Corresponding Author: Herb von Schroeder, Toronto Western Hospital, 399 Bathurst Street, Hand Clinic 2 East, Toronto, On M5T 2S8 Canada. Phone: (416) 603-5641. Fax: (416) 603-5813. E-mail: herb.vonschroeder@uhn.ca. Other authors: meir@biomimeticstechnologies.com; weyand.birgit@ mh-hannover.de; syed@biomimeticstechnologies.com; vogt.peter@mh-hannover.de. §Authors contributed equally. 
In order to prevent cell death, some bioreactors have been proposed based on rotational designs to mimic a micro-gravity environment including a membrane exchange unit for metabolites and gases [5]. The rotational bioreactor design was initially developed by NASA [6, 7]. Such rotational models have been shown to reduce the hydrodynamic shear by approximately 10-fold [8]. Low shear is important to maintain cell viability and tissue structure. Another example of a rotational bioreactor that includes design properties to increase mass transfer and support large aggregates of cells is the laminar Taylor vortex that maintains oxygenation for long-term cell culture [9]. However, a limitation with this design is that the tissue size cannot be adequately controlled and the growth of large amount of cells in the scaffold remains a challenge $[10,11]$. Other bioreactor designs incorporated medium stirring or cell suspension methodologies such as microcarrier-based cultures [5, 12, 13].

The impact of shear forces on mammalian cell's growth and function due to their lack of stable cell walls compared to plant cells has been noted since early advances in mammalian cell culture in the late 1980s, leading to the use of bioreactors in order to enhance cell expansion and to improve culture conditions [14, 15]. Experimental studies on suspension-adapted mammalian cells found turbulent shear more damaging to cells than laminar shear of the same magnitude $[16,17]$. Results from studies of shear impact on adherent mammalian cells in $2 \mathrm{D}$ and $3 \mathrm{D}$ culture demonstrated multiple influences on cell proliferation, cell attachment and cell differentiation [17, 18, 19]. Since responses differ among cell types and sources as well as variable culture and stress conditions, there is a need particularly for well-defined 3D culture systems for comparison of standardized cell culture [20].

Bioreactor designs are different between industrial and laboratory small-scale applications. The latter designs are commonly for research purposes, but cannot be transferred to industrial scale for the growth of clinically useful amount of tissues, since increasing the sizes of these types of bioreactors results in detrimentally large shear forces $[4,21,22]$. An example of industrial scale bioreactors is the Air Lift Bioreactor [23] which is a low energy input, high-yield alternative to stirred tank bioreactors that manages to achieve good oxygen transfer with low fluid shear [24, 25]. A limitation of the Air Lift Bioreactor is the mixing of mass transfer and oxygen availability limiting cell growth [26], and not allowing cultivation for high cell density required for practical application [27].

It is the objective of this work to define and improve the physical environment of a bioreactor using a computational fluid dynamics (CFD) model that would allow for scaling-up from research size to industrial size, improving efficiency and increasing cell density in a controlled flow environment. This study focuses on flow perfusion bioreactors that allow for the design including features such as variable ('tided') flow, control of the flow through regions of least resistance and maintaining the flow through the scaffold [28].

\section{METHODS}

\subsection{Geometrical Model \& Mesh Model}

Bioreactor models were sketched using Pro/Engineering 2000i (PTC, Needham, Massachusetts, USA). With Pro/Engineering, sketching in three dimensions was useful for progressive design modifications, and the sketches were compatible with the mesh 
used for flow simulations. The three designs considered in this study included a standard reactor with a double-bell-shape vessel (design 1, see Figure 1), a pipe with a cylindrical vessel (design 2, see Figure 4), and a standard reactor with internal irises (design 3, see Figure 7A and 7B).

The mesh of the bioreactor model was prepared using GAMBIT (ANSYS, Inc., Canonsburg, Pennsylvania, USA). A cross-section of the model was composed of 35000 (design 1), 65000 (design 2) and 80000 tetrahedral elements (design 3), respectively. For design 3 , the porous region as well as the irises required a smaller mesh of $1.27 \times 10^{-3} \mathrm{~m}$ when the flow path becomes very narrow (Figure 7A and 7B). The larger areas of fluid flow were meshed by $5.98 \times 10^{-3} \mathrm{~m}$. After transfer of the mesh into the CFD modeling software (FLUENT software, ANSYS, Inc. Canonsburg, Pennsylvania, USA), the grid was checked and scaled in inches.

\subsection{Scaffold Properties}

The scaffold was simulated with a uniform porous medium model. The scaffold porosity was set within the range of $70-90 \%$ since the porosity for bone tissue is approximately $78 \%$ [29]. In order to mimic various stages of cell proliferation within the porous scaffold, 5 different permeability values representing different stages of cell growth were chosen according to the literature [30, 31, 32]. Scaffold thickness was set at $1 \mathrm{~cm}$ prior to scaling. Parameters for modeling of flow through porous media are summarized in Table 1. The mean particle diameter $D_{p}$ is determined from the Ergun equation (eqn. 5) below.

\subsection{CFD Simulation \& Boundary Conditions}

CFD modeling was performed using FLUENT software (ANSYS, Inc. Canonsburg, Pennsylvania, USA). A CFD simulation with the following parameters and boundary conditions was performed: axisymmetric model, segregated solver, laminar fluid flow, incompressible Newtonian fluid with the viscosity of water at $37^{\circ} \mathrm{C}$ (the cell culture medium has similar physical properties as water), no-slip boundary conditions on walls, atmospheric operating pressure and reference pressure location $[0,0]$. The inlet of the bioreactor was set in terms of either mass flow rate or velocity. For calculation of mass flow rate in $\mathrm{kg} \mathrm{s}^{-1}$, the components of flow directions were set as $[0,-1]$. For flow

Table 1. Scaffold parameters for CFD simulation

\begin{tabular}{lcccc}
\hline Permeability, & $\begin{array}{c}\text { Porosity, } \\
\boldsymbol{\kappa}, \mathbf{~ m}^{\mathbf{2}}\end{array}$ & $\begin{array}{c}\text { Viscous resistance } \\
\text { coefficient, } \\
\mathbf{1} / \boldsymbol{\kappa}, \mathbf{1} / \mathbf{m}^{\mathbf{2}}\end{array}$ & $\begin{array}{c}\text { Inertial resistance } \\
\text { coefficient, } \\
\mathbf{C}_{\mathbf{2}}, \mathbf{1} / \mathbf{m}\end{array}$ & $\begin{array}{c}\text { Particle diameter, } \\
\boldsymbol{D}_{\boldsymbol{p}}, \mathbf{m}\end{array}$ \\
\hline $4.5200 \times 10^{-13}$ & $8.0000 \times 10^{-1}$ & $2.2124 \times 10^{12}$ & $5.9404 \times 10^{5}$ & $2.3015 \times 10^{-6}$ \\
$5.0000 \times 10^{-12}$ & $8.0000 \times 10^{-1}$ & $2.0000 \times 10^{11}$ & $1.7861 \times 10^{5}$ & $7.6547 \times 10^{-6}$ \\
$5.0000 \times 10^{-11}$ & $8.0000 \times 10^{-1}$ & $2.0000 \times 10^{10}$ & $5.6481 \times 10^{4}$ & $2.4206 \times 10^{-5}$ \\
$5.0000 \times 10^{-10}$ & $8.0000 \times 10^{-1}$ & $2.0000 \times 10^{9}$ & $1.7861 \times 10^{4}$ & $7.6547 \times 10^{-5}$ \\
$5.0000 \times 10^{-9}$ & $8.0000 \times 10^{-1}$ & $2.0000 \times 10^{8}$ & $5.6481 \times 10^{3}$ & $2.4206 \times 10^{-4}$
\end{tabular}


velocity simulations, the inlet velocity was set at $7.34 \times 10^{-5} \mathrm{~m} \mathrm{~s}^{-1}$ [33]. The convergence criterion was set at 0.001 for continuity, $x$-velocity and y-velocity. The number of iterations was set at 500 and if there was no convergence, factors for pressure and momentum were adjusted until the solution converged. Plots of flow velocity, pressure, velocity vectors and flow path lines were generated for the fluid analysis.

\subsection{Flow Characterization}

Laminar flow is determined by the Reynolds number. When fluid moves smoothly in parallel layers and the Reynolds number is lower than the critical value of 2000, the flow is assumed to be laminar, whereas for Reynolds numbers above 3000, the flow is considered to be turbulent [34]. The Reynolds number is calculated as

$$
\operatorname{Re}=V \times d / v
$$

where $V$ is the average flow velocity, $d$ is the diameter of the bioreactor and $v$ is the kinematic viscosity of water with $v=10^{-6} \mathrm{~m}^{2} \mathrm{~s}^{-1}=1 \mathrm{cSt}$ at $20^{\circ} \mathrm{C}$ [35]. The average flow velocity $V$ is obtained from

$$
Q=V \times A
$$

where $Q$ is the volumetric flow rate and $A$ is the cross-sectional flow area with

$$
A=\pi \times d^{2} / 4
$$

For laminar flow of viscous fluids, the velocity increases towards the center of the scaffold and is a function of the radial location. The velocity is also inversely proportional to the viscosity of the fluid [36]. The viscosity and permeability for the simulation are related by Darcy's Law [18, 36, 37]:

$$
\frac{Q}{A}=\left(\frac{\kappa}{\mu}\right) \times\left(\frac{\Delta P}{L}\right)
$$

where $\kappa$ is the hydrodynamic permeability, $\mu$ is the dynamic viscosity (considered to be the same as water at $20^{\circ} \mathrm{C}$ with $0.001 \mathrm{~Pa} \mathrm{~s}$ ), $\Delta P$ is the pressure drop across the porous scaffold, and $L$ is the thickness of the scaffold.

The Ergun equation below can be applied to calculate the pressure drop across a porous medium (packed bed model) by linearly combining the Blake-Kozeny model for laminar flow with the Burke-Plummer model for turbulent flow (the first and second terms on the right side of eqn. 5 , respectively) $[38,39]$ :

$$
\frac{\Delta P}{L}=\frac{150 \mu(1-\varepsilon)^{2} V}{D_{p}^{2} \varepsilon^{3}}+1.75 \times \frac{(1-\varepsilon) \rho V^{2}}{\varepsilon^{3} D_{p}}
$$


where $\varepsilon$ is the porosity of the scaffold, $\rho$ is the density of the fluid and $D_{p}$ is the mean particle diameter of the porous medium [39]. Related to this equation, the viscous resistance coefficient $1 / \kappa$ (which dominates at low $R e$ ) and the inertial resistance coefficient $C_{2}$ (which dominates at high $\mathrm{Re}$ ) can be derived as follows [40]:

$$
\begin{aligned}
& \frac{1}{\kappa}=\frac{150(1-\varepsilon)^{2}}{D_{p}^{2} \times \varepsilon^{3}} \\
& C_{2}=\frac{3.5(1-\varepsilon)}{D_{p} \times \varepsilon^{3}}
\end{aligned}
$$

\subsection{Prototype testing and cell culture conditions}

Human adipose mesenchymal stem cells were derived from fat tissue of donors undergoing abdominoplasty after obtaining approval from the Research Ethics Committee and informed consent from the patients. Briefly, cells were isolated by collagenase digestion and sequential centrifugation according to standard protocols [41]. Adipose mesenchymal stem cells were expanded in standard culture medium (DMEM-F12 (PAA laboratories, US), 5\% FCS, supplemented with antibiotics, sodium pyuvate and non-essential amino-acids (all Biochrom, US)) and then seeded onto macroporous ceramic scaffolds (Sponceram ${ }^{\circledR}$ Zellwerk GmbH, Germany). Scaffolds were cultured under static conditions in a Petri dish inside a cell culture incubator at $37^{\circ} \mathrm{C}, 5 \% \mathrm{CO}_{2}$, and under dynamic condition within the bioreactor prototype with continuous perfusion of $1 \mathrm{ml} / \mathrm{min}$ via a peristaltic pump (Ismatec, Germany) at $37^{\circ} \mathrm{C}$ for 1 month in standard culture medium with HEPES buffer solution at $0.01 \mathrm{M}$ (PAA Laboratories, US). Scaffold were stained with fluorescein diacetate 2,4 $\mathrm{mmolL}^{-1}$ (Sigma, Germany), washed with phosphate buffer saline (PAA laboratories, US) and cell vitality was analysed via stereomicroscopy (Olympus SZX16).

\section{RESULTS}

\subsection{Design 1}

The primary design was based on a standard perfusion bioreactor [42]. The mesh model by GAMBIT is presented in Figure 1.

Flow simulations by FLUENT revealed significant problems with flow stagnation as well as relevant pressure build-up upstream of the reactor as demonstrated in Figure $2 \mathrm{~A}$ and $\mathrm{B}$. There was a significant decrease in flow velocity across the scaffold, which might adversely affect mass transport and oxygen transfer to the cells in the scaffold.

Figure 3 shows the distribution of flow vectors which are not parallel (laminar) downstream of the scaffold. These results suggest that this design of the bioreactor needs to be improved in order to reduce flow stagnation and irregularities. 


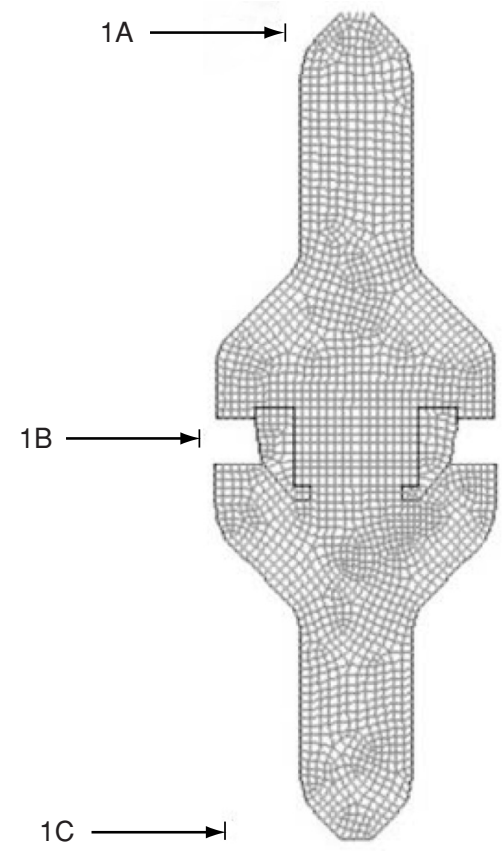

Figure 1. Mesh of bioreactor design 1. 1A: flow inlet. 1B: scaffold. 1C: flow outlet.

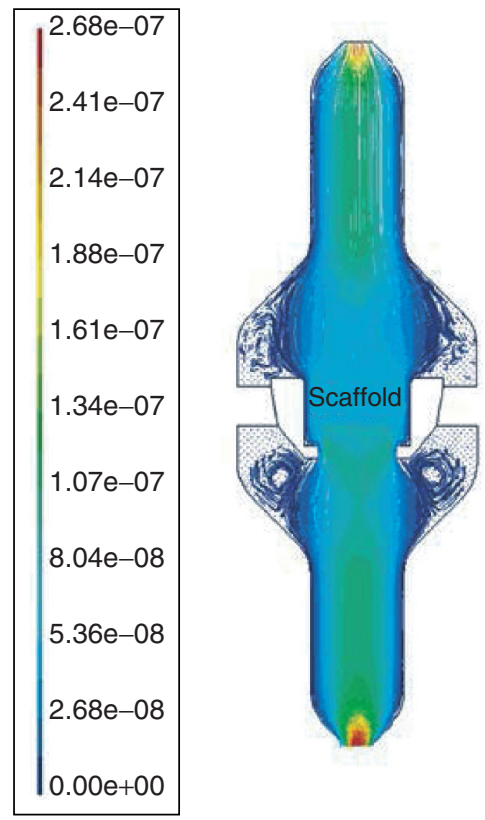

Figure 2A. Flow path lines of bioreactor design 1 show significant stagnation above and below scaffold level (velocity values in $\mathrm{m} \mathrm{s}^{-1}$; e- $08=\times 10^{-8}$ ). 


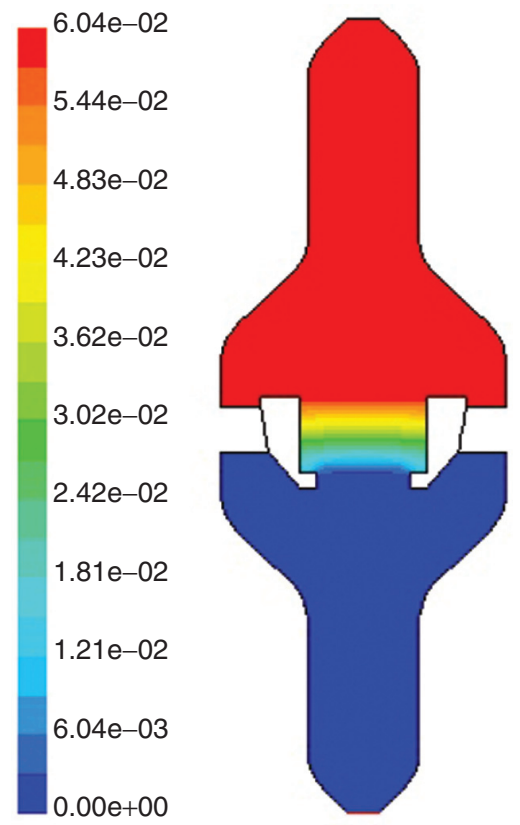

Figure 2B. Pressure distribution of bioreactor design 1 reveals significant pressure build-up upstream of scaffold (pressure values in Pa; e-02 $=\times 10^{-2}$ ).

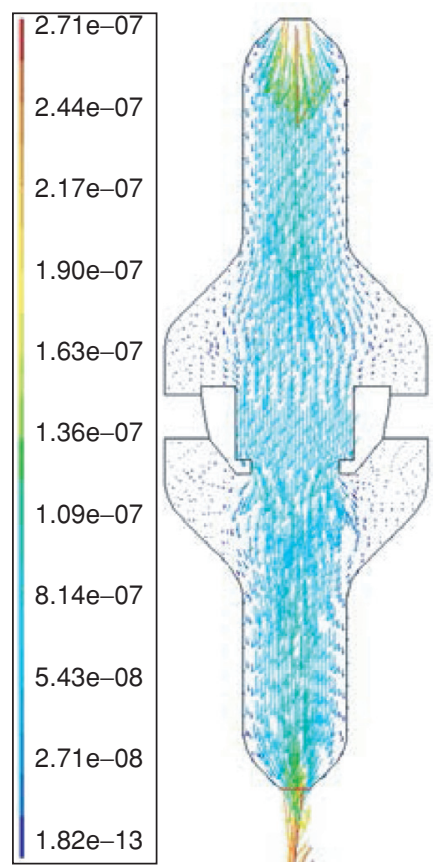

Figure 3. Flow vectors of bioreactor design 1 show irregular currents downstream of scaffold, suggesting turbulence (velocity values in $\mathrm{m} \mathrm{s}^{-1}$; e-08 $=\times 10^{-8}$ ). 


\subsection{Design 2}

Based on the CFD results of design 1, the geometry of the bioreactor was modified to resemble a pipe in order to optimize flow patterns. Figure 4 shows the GAMBIT mesh of bioreactor design 2 .

Results of flow simulation by FLUENT software are presented in Figures 5 and 6 , demonstrating flow path lines more regular with less stagnation (Figure 5A) but there was still a significant pressure build-up in the upper half of the vessel (Figure 5B). Flow vectors are more regular and parallel to each other, suggesting laminar flow pattern, than in design 1, as shown in Figure 6.

\subsection{Design 3}

Deficiency of both of the previous designs led to the introduction of a third design. From the simulation results of those designs, we learned that a bypass system would be conducive to releasing pressure build-up in the system and preventing flow irregularities. Therefore, irises were introduced to our design 3 in order to control the flow and pressure in the bioreactor $[43,44]$. The iris system opens and closes like the iris of eye, and can be controlled by pressure sensors installed upstream and downstream of the scaffold in the bioreactor. Although the openings of these irises were adjustable, they were set as completely closed or completely open in our simulation. Figure 7 demonstrates the mesh for design 3 using GAMBIT solid geometry Modeler and GAMBIT mesh modeler given the flow domain. Figure 7A shows the design with closed irises, where the main flow field was meshed with a mesh size of $5.98 \times 10^{-3} \mathrm{~m}$. In order to model the design with open irises as shown in

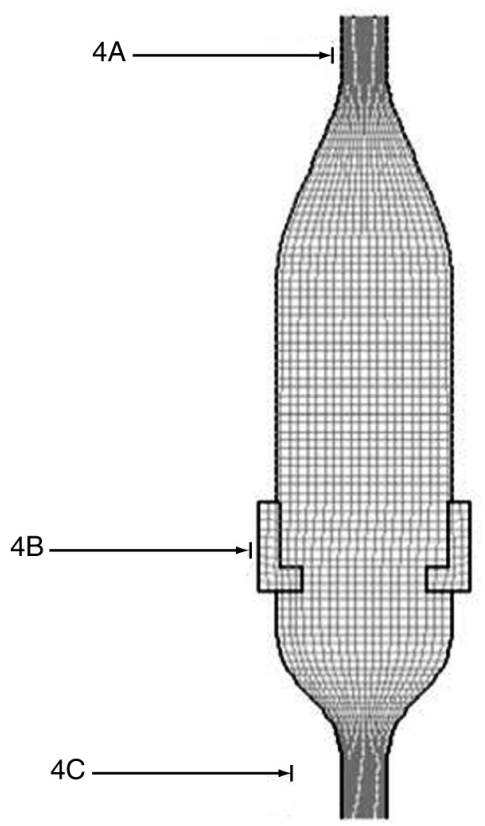

Figure 4. Mesh of bioreactor design 2. 4A: flow inlet. 4B: scaffold position. 4C: flow outlet. 


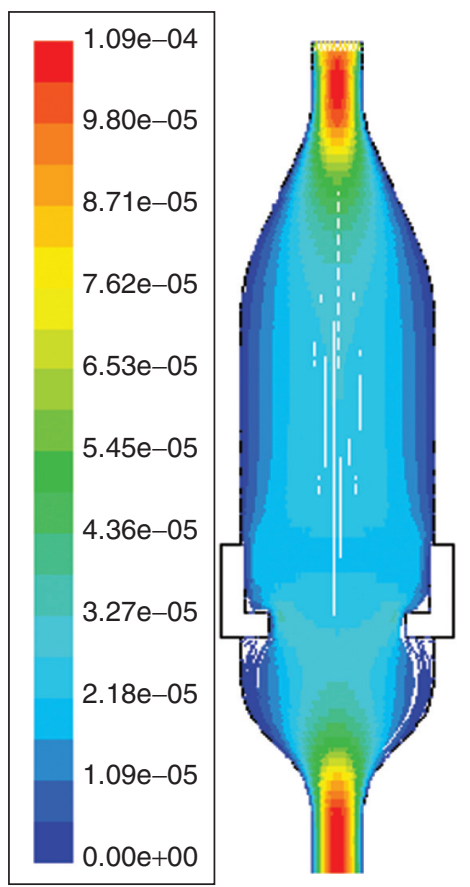

Figure 5A. Flow path lines of bioreactor design 2 show less stagnation compared to design 1 (velocity values in $\mathrm{m} \mathrm{s}^{-1}$; e- $05=\times 10^{-5}$ ).

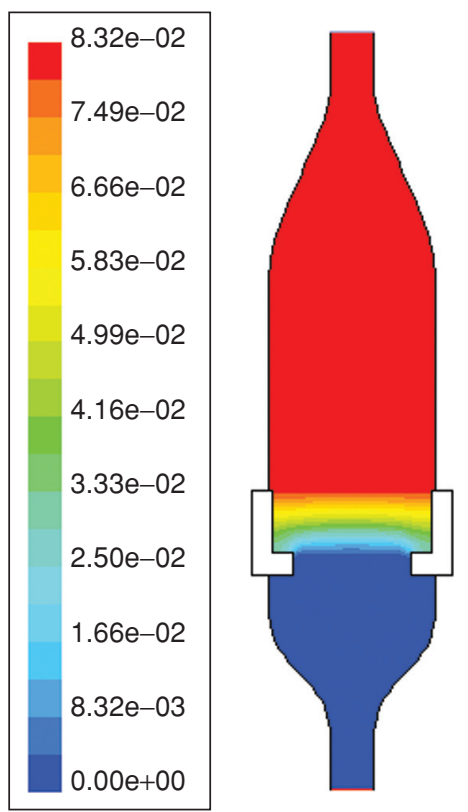

Figure 5B. Pressure distribution of bioreactor design 2 (pressure values in $\mathrm{Pa}$; $\mathrm{e}-02=\times 10^{-2}$ ). 


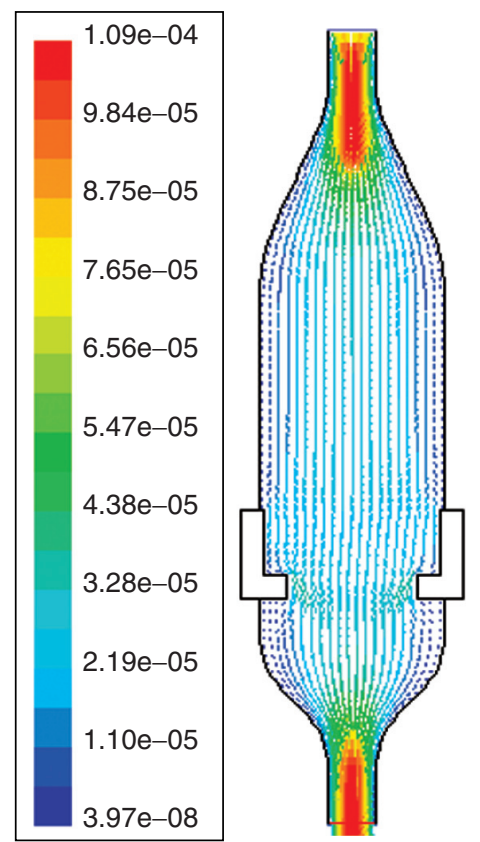

Figure 6. Flow vectors of bioreactor design 2 are more regular compared to design 1 (velocity values in $\mathrm{m} \mathrm{s}^{-1}$; e- $05=\times 10^{-5}$ ).

Figure $7 \mathrm{~B}$, a finer mesh size of $1.27 \times 10^{-3} \mathrm{~m}$ was adopted since the open flow path became very narrow.

CFD simulations of design 3 exemplary for some scaffold permeability values (Table 1) are exhibited in Figure 8 (flow path lines) and Figure 9 (pressure drop across scaffold) for closed irises, as well as in Figure 10 (flow path lines) and Figure 11 (pressure drop across scaffold) for open irises.

When irises were closed, fluid flow did not converge for the lowest permeability $4.5 \times$ $10^{-13} \mathrm{~m}^{2}$ and $5 \times 10^{-12} \mathrm{~m}^{2}$, and even with open irises, there were some flow irregularities for these values of permeability (Figure $10 \mathrm{~A}$ ). However, at higher values of permeability, there was laminar flow at scaffold level when irises were open (Figure $10 \mathrm{~B}-\mathrm{D})$. Opening of the iris system significantly reduced the pressure drop across the scaffold from $1.05 \mathrm{~Pa}$ to $2.0 \times 10^{-3} \mathrm{~Pa}$ (Figures 9 and 11 , simulated for permeability of $5 \times 10^{-9} \mathrm{~m}^{2}$ ).

Figure 12 presents a closer view of pressure distribution at scaffold level for closed (Figure 12A) and open irises (Figure 12B). The calculated Reynolds number with closed irises was 2942, indicating turbulence with high pressure drop and shear, while opening of the iris reduced the Reynolds number to 641, indicating laminar flow. Table 2 summarizes results of CFD simulation for pressure distribution of the three designs, where opening of the iris system in design 3 allows decrease of high pressure upstream of the scaffold. 


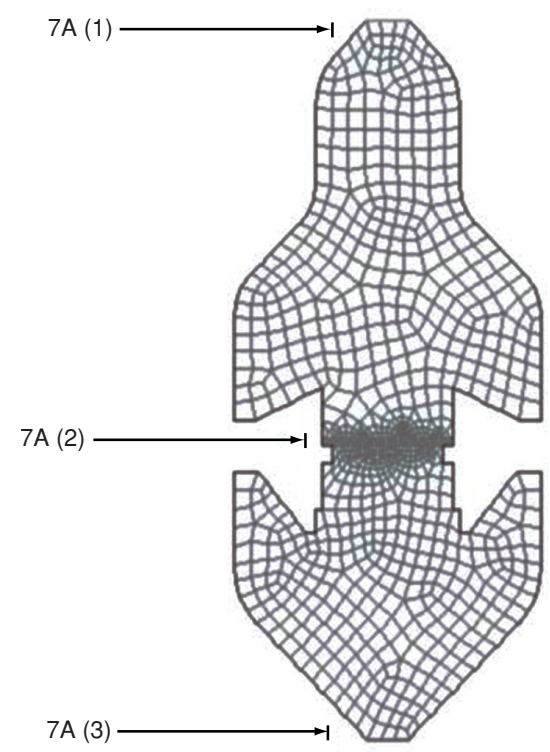

Figure 7A. Mesh for bioreactor design 3 with a mesh size of $5.98 \times 10^{-3} \mathrm{~m}$ for the main flow field and finer mesh size of $1.27 \times 10^{-3} \mathrm{~m}$ at the scaffold level. 7A(1): flow inlet. 7A(2): scaffold. 7A(3): flow outlet.

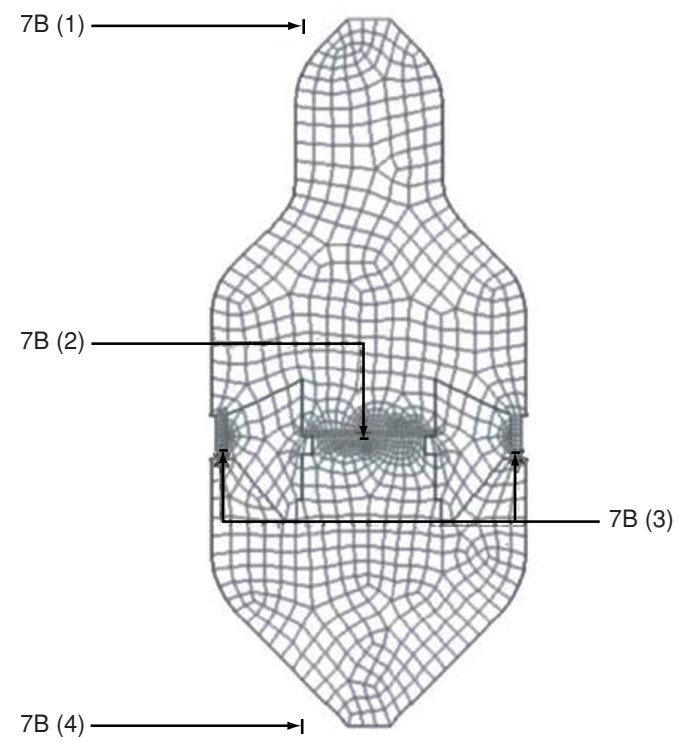

Figure 7B. Mesh for bioreactor design 3 with irises also meshed with a finer mesh size of $1.27 \times 10^{-3} \mathrm{~m}$. $7 \mathrm{~B}(1)$ : flow inlet. $7 \mathrm{~B}(2)$ : scaffold. $7 \mathrm{~B}(3)$ : iris system. $7 \mathrm{~B}(4)$ : flow outlet. 

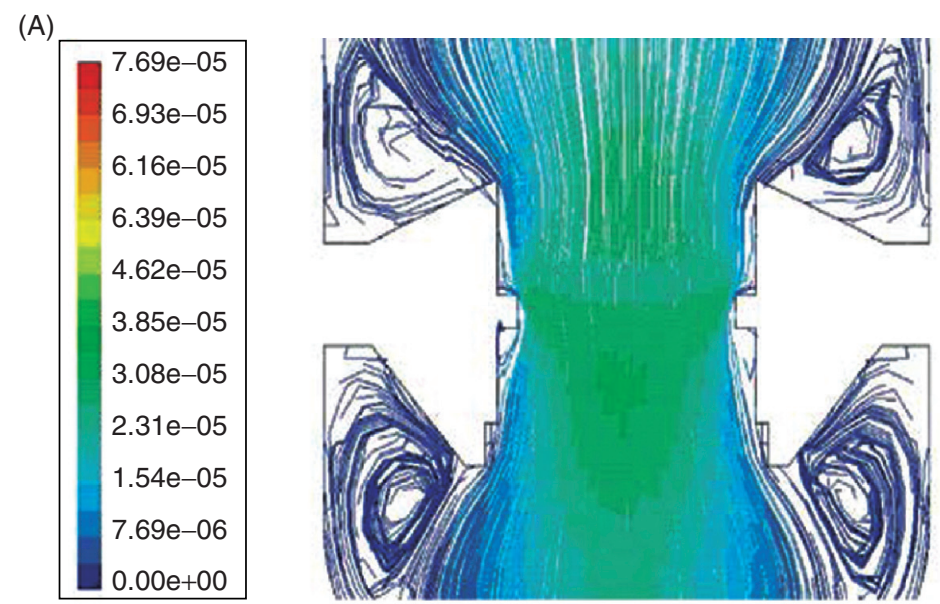

(B)

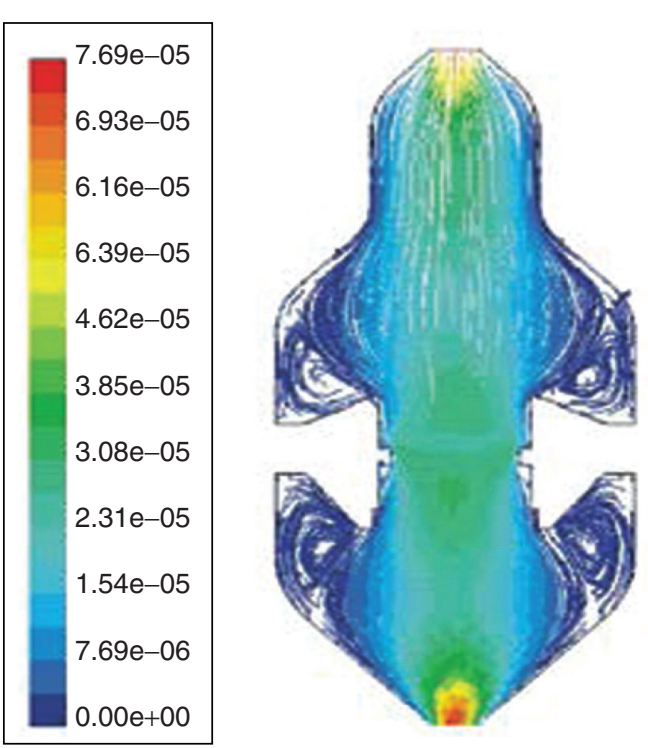

Figure 8. Flow path lines of bioreactor design 3 with closed irises showing some stagnation at scaffold level (A) and full view (B) (velocity in $\mathrm{m} \mathrm{s}^{-1}$; e-05 $=\times 10^{-5}$, permeability $\left.=5 \times 10^{-9} \mathrm{~m}^{2}\right)$.

Based on results of the CFD modeling, a prototype reactor was built as shown in Figure 13. Results of biological experiments with human adipose mesenchymal stem cells cultured in a macroporous ceramic scaffold demonstrated constant high cellular viability after 1 month of dynamic culture within the bioreactors, as shown in Figure 14A, in contrast to static culture in the Petri dish (Fig 14B). 


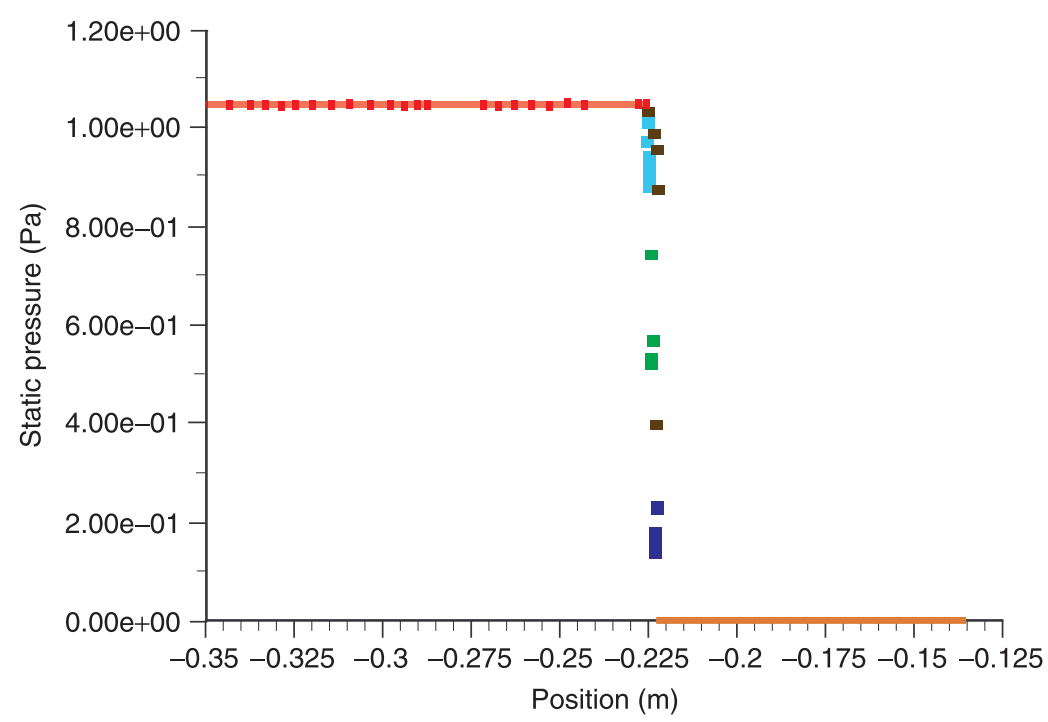

Figure 9. Pressure variation across the scaffold in bioreactor design 3 showing pressure drop of $1.05 \mathrm{~Pa}$ at the scaffold for permeability $5 \times 10^{-9} \mathrm{~m}^{2}$ (inlet location $-0.35 \mathrm{~m}$, scaffold location $-0.225 \mathrm{~m}$, outlet location $-0.125 \mathrm{~m}$ ).

\section{DISCUSSION}

Different perfusion bioreactors have been developed for tissue engineering applications, especially for bone tissue engineering [28, 45, 46]. However, many systems were characterized only by perfusion rate and lack substantial information about shear stress within the reactor vessel [47]. The results of our study suggest that reactor geometry has a significant impact on flow perfusion and pressure distribution around the scaffold. Common designs such as bell-shaped and cylindrical vessels cannot guarantee continuous perfusion across scaffolds without creating areas of flow stagnation or pressure build-up, as demonstrated in our CFD simulation results. Furthermore, our results show that increase in permeability of the scaffold due to cellular growth has an impact on flow vectors and pressure distribution.

In our approach, we focused on modeling of flow path lines within a reactor vessel and across the scaffold with different values of permeability due to cellular growth. However, we did not study the shear stress within the scaffold itself. For this issue, the interconnectivity and tortuosity of scaffold pores as well as cellular growth within the pores need to be considered [48]. Calculations will require precisely defined scaffold geometry through, e.g., CT scanning, and infinite elements analysis tools [49, 50]. Recent studies on CFD modeling have been performed on modeling fluid flow through regular and irregular scaffolds during perfusion without considering reactor shape $[51,52,53,54]$.

From the analysis of the different designs, it was apparent that optimizing the geometry of the reactor was necessary to reduce flow irregularities. Designs 2 and 3 did 
(A)

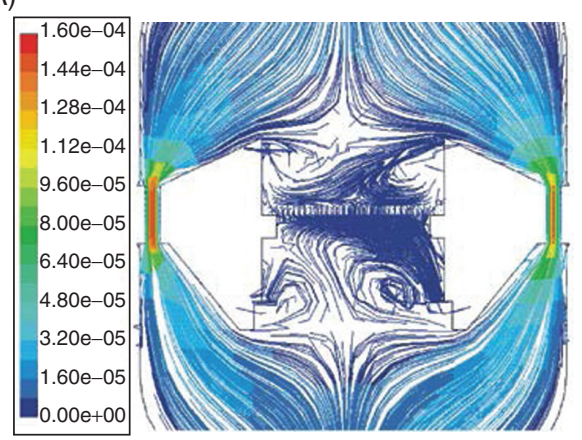

(C)

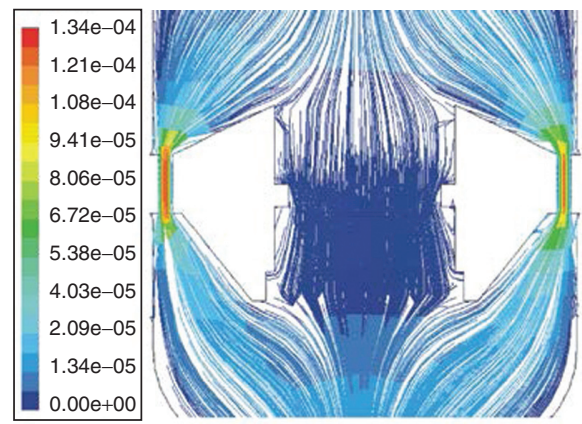

(B)

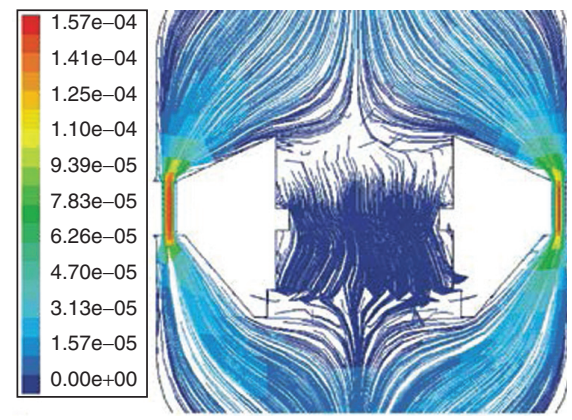

(D)

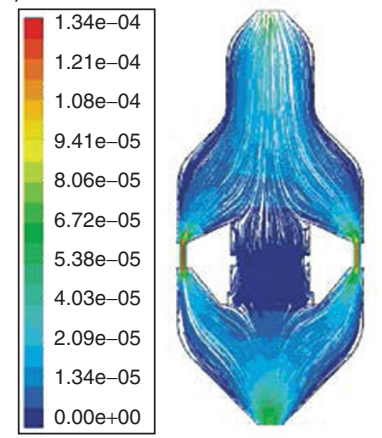

Figure 10. Flow path lines of bioreactor design 3 with open irises showing some flow perturbation at a low permeability of $5 \times 10^{-12} \mathrm{~m}^{2}(\mathrm{~A})$, laminar flow at higher values of permeability of $5 \times 10^{-10} \mathrm{~m}^{2}(\mathrm{~B})$ and $5 \times 10^{-9}$ $\mathrm{m}^{2}(\mathrm{C})$, and a full view for $5 \times 10^{-9} \mathrm{~m}^{2}$ permeability (D) (velocity in $\mathrm{m} \mathrm{s}^{-1}$; $\left.\mathrm{e}-05=\times 10^{-5}\right)$.

not have as much flow stagnation as design 1, even when the irises in design 3 were closed. The pressure build-up in design 2 was undesirable despite its regular flow pattern with little stagnation.

A novel approach in our design 3 is the internal bypass system in the form of irises which successfully reduced upstream pressure build-up due to cellular growth within the scaffold. Furthermore, opening of the iris reduced the Reynolds number to change the flow pattern from turbulent to laminar flow. The iris system however requires a fine balance since its size can determine the amount of perfusion through the scaffold as well as the pressure drop across the scaffold. By balancing with the iris system, a laminar flow can be achieved within the bioreactor despite cellular growth in the scaffold.

The benefit of laminar flow for tissue engineering needs further experimental evaluation. This flow pattern might be advantageous to support cell proliferation and extracellular matrix formation within a scaffold; however, both of which lead to a decrease in scaffold permeability and an increase in shear stress [53, 55]. In bone 


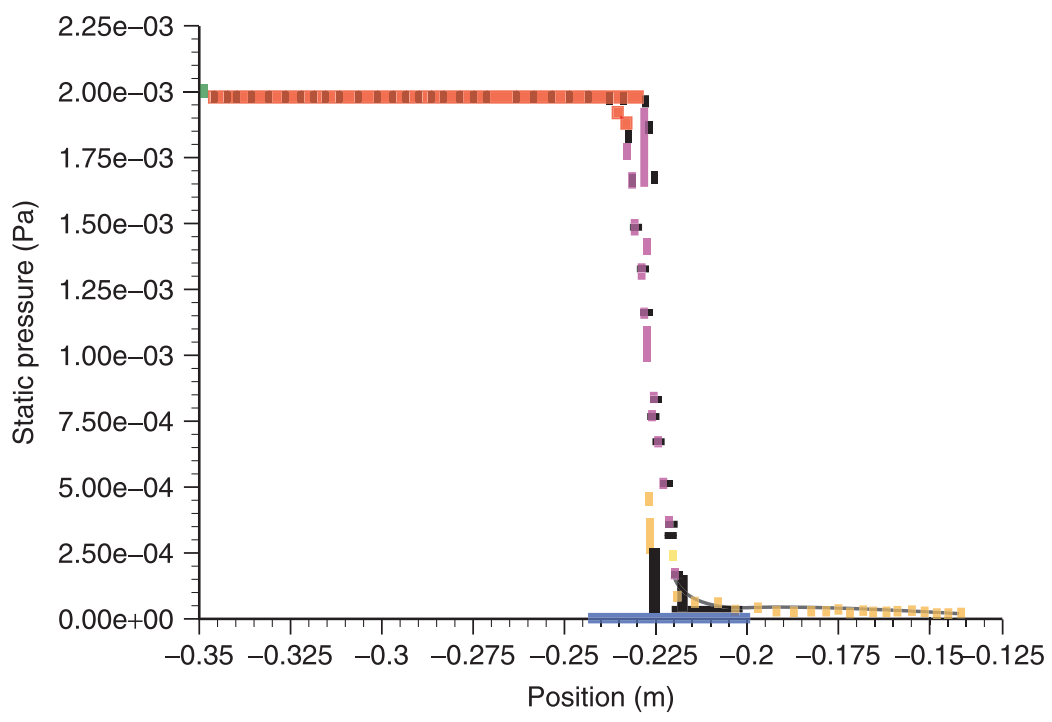

Figure 11. Pressure variation across the scaffold in bioreactor design 3 with open irises, showing significantly reduced pressure drop of $2 \times 10^{-3} \mathrm{~Pa}$ at the scaffold for permeability of $5 \times 10^{-9} \mathrm{~m}^{2}$ (inlet position $-0.35 \mathrm{~m}$, scaffold position $-0.225 \mathrm{~m}$, outlet position $-0.125 \mathrm{~m}$ ).

(A)

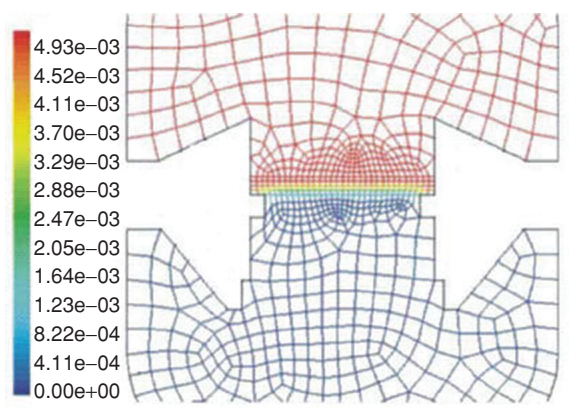

(B)

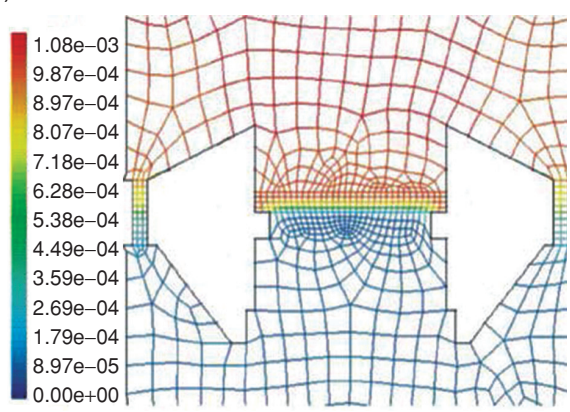

Figure 12. Pressure distribution of bioreactor design 3 around the scaffold with closed (A) and open (B) irises. (Pressure in Pa; e-04 $=\times 10^{-4}$ ).

Table 2. Comparison of CFD simulation results for pressure variation across the scaffold in different designs of bioreactor

\begin{tabular}{lcccc}
\hline & & & \multicolumn{2}{c}{ Design 3 } \\
\cline { 3 - 5 } & Design 1 & Design 2 & Irises closed & Irises open \\
\hline Upstream Pressure $[\mathrm{Pa}]$ & $6.04 \times 10^{-2}$ & $8.32 \times 10^{-2}$ & $4.93 \times 10^{-3}$ & $1.08 \times 10^{-3}$ \\
Downstream Pressure $[\mathrm{Pa}]$ & 0 & 0 & 0 & $8.97 \times 10^{-5}$
\end{tabular}




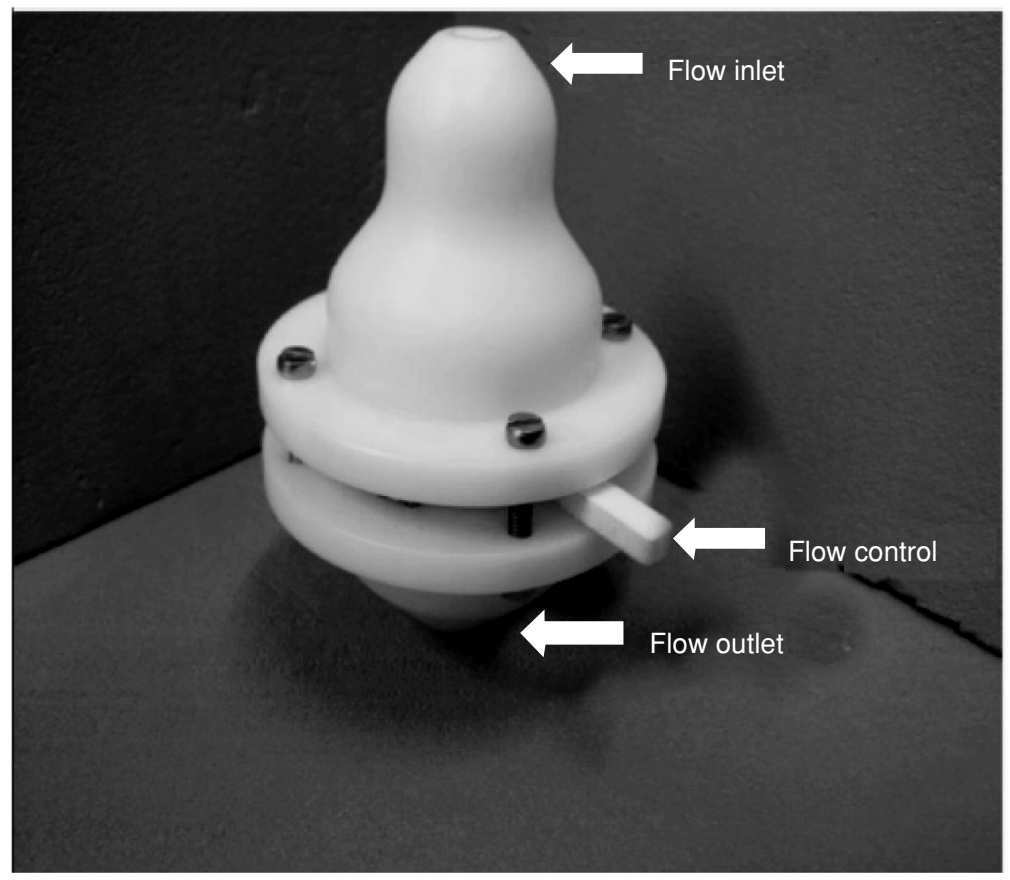

Figure 13. Prototype bioreactor based on design 3.

(A)

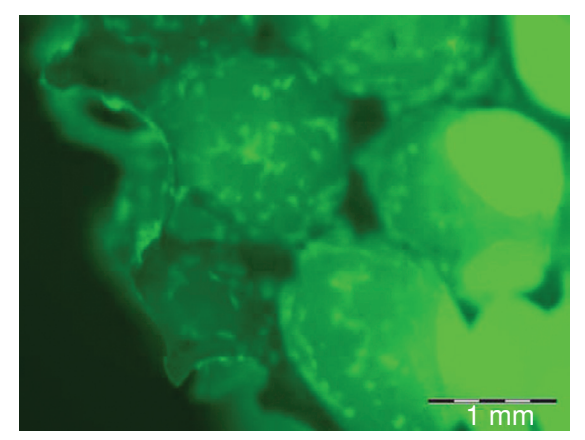

(B)

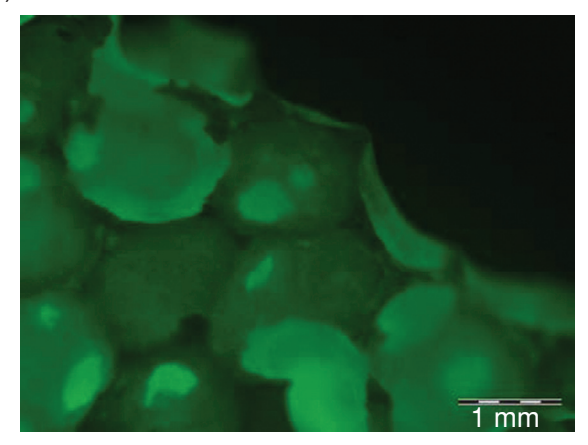

Figure 14. Dynamic cultivation of cell-seeded scaffolds in the prototype bioreactor promotes cell vitality in contrast with static culture. Adipose mesenchymal stem cells are cultivated on a macorporous ceramic scaffold (section) for 1 month under continuous perfusion in the bioreactor (A) versus static culture in a Petri dish (B). Cells were stained with fluorescein diacetate and observed under an Olympus stereomicroscope. 
tissue engineering, osteogenic differentiation is stimulated by higher perfusion rate in perfusion bioreactors where turbulent flow patterns may occur [56]. Interestingly, the shear stress required to induce osteogenic differentiation of cells have been found to be two to three orders of magnitude $\left(10^{2}\right.$ to $\left.10^{3}\right)$ higher in two-dimensional perfusion chambers than in three-dimensional cultures [57]. The results with our prototype bioreactor also demonstrate a benefit of laminar flow compared to static culture conditions in respect to cell viability and osteogenic differentiation of adiposederived stem cells [58]. Scaling of the model as performed in the current approach will allow volume increase of the reactor to an industrial size without change of the internal flow pattern.

In order to further optimize CFD prediction of the model, additional mesh refinement would be required, for which as many square edges in the mesh as possible have to be removed, especially in the area around the tissue and scaffold. Since our system considers fluid pressure in a finite element model, the flow creates a displacement deformation and therefore the mesh needs to minimize the square surfaces [59].

A problem with utilizing software for the CFD simulations is the limitations of the software (FLUENT was employed in the present study) itself in simulating flow across low-permeability media. The results could be improved with a more powerful software capable of solving flow under very low permeability.

A further improvement of the bioreactor design can be achieved by threedimensional CFD modeling to characterize the flows through the scaffold and the irises. However, a complete three-dimensional modeling of flow is very costly with respect to computer time or hardware, even if using open source software. Furthermore, turbulent flow needs to be analyzed by solving the Navier-Stokes equation which could be very difficult and costly [59]. Other approaches employed Lattice Boltzmann equation which requires many very small increments for optimization of the turbulence $[60,61,62]$. We are currently working on three-dimensional modeling of the bioreactor in order to resolve issues of turbulence and specify flow patterns based on scaffold properties and dimensions of the irises.

One of the major considerations for any bioreactor design is the support of cell proliferation. This also includes formation of extracellular matrix as a provider for cellular three-dimensional arrangement. The Reynolds number in the reactor affects cell proliferation and extracellular matrix formation. Studies are still needed to examine the effect of physical stresses on cellular behaviour, cell growth, extracellular matrix formation and cell differentiation which depends on the cell type. Further interesting issues are how cells sense changes in the extracellular environment, and how changes in the extracellular matrix content and composition change cell physiology (e.g., during the mineralization process of bone callus tissue in fracture healing). Three-dimensional cell culture differs significantly from the standard two-dimensional cell culture in a Petri dish where overcrowding often leads to cell growth arrest and cell death $[63,64$, 65]. The biological complexity always needs to be considered for optimal in vitro 2D and 3D cell culture. With well-characterized bioreactor systems for tissue engineering, we may achieve a better understanding for the essential factors and stimuli for tissue formation, growth and remodeling. 


\section{CONCLUSION}

Different perfusion bioreactor designs were analyzed by CFD software regarding flow pattern and pressure distribution around a porous scaffold with changing permeability representing cell growth. Results demonstrated that common designs such as bell-shaped and cylindrical geometries display regions of flow stagnation and flow irregularities as well as pressure build-up upstream of the scaffold. Laminar flow was achieved by introducing an internal iris system acting as bypass to regulate pressure drop and flow path lines after permeability decreased due to cellular growth within the scaffold. Using irises to control fluid flow, we have developed a method to overcome many limitations of flow patterns in current bioreactor systems by regulating the pressure. The advancement of tissue engineering will continue towards growing clinically relevant tissues for musculoskeletal reconstruction or organ replacement. This advancement requires bioreactors of high performance. Our data demonstrate that bioreactor geometry can have a significant impact on internal flow patterns and pressure distributions. CFD modeling provides a useful tool to improve bioreactor design.

\section{ACKNOWLEDGEMENTS}

The authors wish to thank Dr. Ibraheem Swaish of the Institute for Complex Engineering at Carnegie Mellon University, Pittsburgh, USA for help with the FLUENT simulations and GAMBIT analysis and Dipl.-Math. Olaf Schmidt from the Institut für Getriebetechnik of Gottfried Wilhelm Leibniz University of Hannover, Germany for help with drawings of the models used in FLUENT.

\section{CONFLICT OF INTEREST:}

\section{None.}

\section{NOMENCLATURE}

$\begin{array}{ll}A & \text { cross-sectional flow area, } \mathrm{m}^{2} \\ C_{2} & \text { inertial resistance coefficient, } \mathrm{m}^{-1} \\ d & \text { diameter of bioreactor, } \mathrm{m} \\ D_{p} & \text { mean particle diameter, } \mathrm{m} \\ L & \text { thickness of scaffold, } \mathrm{m} \\ P & \text { pressure, Pa } \\ Q & \text { volumetric flow rate, } \mathrm{m}^{3} \mathrm{~s}^{-1} \\ \mathrm{Re} & \text { Reynolds number, dimensionless } \\ V & \text { average flow velocity, } \mathrm{m} \mathrm{s}^{-1} \\ & \\ \text { Greek } & \\ \varepsilon & \text { porosity, dimensionless } \\ \kappa & \text { hydrodynamic permeability, } \mathrm{m}^{2} \\ 1 / \kappa & \text { viscous resistance coefficient, } \mathrm{m}^{-2} \\ \mu & \text { dynamic viscosity, Pa-s } \\ v & \text { kinematic viscosity, } \mathrm{m}^{2} \mathrm{~s}^{-1} \\ \rho & \text { density of fluid, kg } \mathrm{m}^{-3}\end{array}$




\section{REFERENCES}

[1] Meyer U, Joos U, Wiesmann HP. Biological and biophysical principles in extracorporal bone tissue engineering. Part I. International Journal of Oral and Maxillofacial Surgery. 2004, 33(4): 325-332.

[2] Margolis L, Hatfill S, Chuaqui R, Vocke C, Emmert-Buck M, Linehan WM, Duray PH. Long term organ culture of human prostate tissue in a NASA-designed rotating wall bioreactor. The Journal of Urology. 1999, 161(1): 290-297.

[3] Cartmell SH, Porter BD, Garcia AJ, Guldberg RE. Effects of medium perfusion rate on cell-seeded three-dimensional bone constructs in vitro. Tissue Engineering. 2003, 9(6): 1197-1203.

[4] Santoro R, Olivares AL, Brans G, Wirz D, Longinotti C, Lacroix D, Martin I, Wendt D. Bioreactor based engineering of large-scale human cartilage grafts for joint resurfacing. Biomaterials. 2010, 31(34): 8946-8952.

[5] Sikavitsas VI, Bancroft GN, Mikos AG. Formation of three-dimensional cell/polymer constructs for bone tissue engineering in a spinner flask and a rotating wall vessel bioreactor. Journal of Biomedical Materials Research. 2002, 62(1): 136-148.

[6] Dutt K, Harris-Hooker S, Ellerson D, Layne D, Kumar R, Hunt R. Generation of 3D retina-like structures from a human retinal cell line in a NASA bioreactor. Cell Transplantation. 2003, 12(7): 717-731.

[7] Rucci N, Migliaccio S, Zani BM, Taranta A, Teti A. Characterization of the osteoblast-like cell phenotype under microgravity conditions in the NASA-approved Rotating Wall Vessel bioreactor (RWV). Journal of Cellular Biochemistry. 2002, 85(1): 167-179.

[8] Pollack SR, Meaney DF, Levine EM, Litt M, Johnston ED. Numerical model and experimental validation of microcarrier motion in a rotating bioreactor. Tissue Engineering. 2000, 6(5): 519-530.

[9] Curran SJ, Black RA. Oxygen transport and cell viability in an annular flow bioreactor: comparison of laminar Couette and Taylor-vortex flow regimes. Biotechnology and Bioengineering. 2005, 89(7): 766-774.

[10] Botchwey EA, Pollack SR, Levine EM, Laurencin CT. Bone tissue engineering in a rotating bioreactor using a microcarrier matrix system. Journal of Biomedical Materials Research. 2001, 55(2): 242-253.

[11] Cummings LJ, Waters SL. Tissue growth in a rotating bioreactor. Part II: fluid flow and nutrient transport problems. Mathematical Medicine and Biology : A Journal of the IMA. 2007, 24(2): 169-208.

[12] Baksh D, Zandstra PW, Davies JE. A non-contact suspension culture approach to the culture of osteogenic cells derived from a CD49elow subpopulation of human bone marrow-derived cells. Biotechnology and Bioengineering. 2007, 98(6): 1195-1208.

[13] Bilgen B, Barabino GA. Location of scaffolds in bioreactors modulates the hydrodynamic environment experienced by engineered tissues. Biotechnology and Bioengineering. 2007, 98(1): 282-294.

[14] Papoutsakis ET. Fluid-mechanical damage of animal cells in bioreactors. Trends in Biotechnology. 1991, 9(12): 427-437.

[15] Born C, Zhang Z, Al-Rubeai M, Thomas CR. Estimation of disruption of animal cells by laminar shear stress. Biotechnology and Bioengineering. 1992, 40(9): 1004-1010.

[16] Kretzmer G, Schugerl K. Response of mammalian cells to shear stress. Applied Microbiology and Biotechnology. 1991, 34(5): 613-616.

[17] Brindley D, Moorthy K, Lee JH, Mason C, Kim HW, Wall I. Bioprocess forces and their impact on cell behavior: implications for bone regeneration therapy. Journal of Tissue Engineering. 2011, Article ID620247: 1-13; doi:10.4061/2011/620247.

[18] Kapur S, Baylink DJ, Lau KH. Fluid flow shear stress stimulates human osteoblast proliferation and differentiation through multiple interacting and competing signal transduction pathways. Bone. 2003, 32(3): 241-251.

[19] Frangos JA, McIntire LV, Eskin SG. Shear stress induced stimulation of mammalian cell metabolism. Biotechnology and Bioengineering. 1988, 32(8): 1053-1060. 
[20] Rauh J, Milan F, Gunther KP, Stiehler M. Bioreactor systems for bone tissue engineering. Tissue Engineering. Part B, Reviews. 2011, 17(4): 263-280.

[21] Cioffi M, Kuffer J, Strobel S, Dubini G, Martin I, Wendt D. Computational evaluation of oxygen and shear stress distributions in 3D perfusion culture systems: macro-scale and micro-structured models. Journal of Biomechanics. 2008, 41(14): 2918-2925.

[22] Kehoe DE, Jing D, Lock LT, Tzanakakis ES. Scalable stirred-suspension bioreactor culture of human pluripotent stem cells. Tissue Engineering. Part A. 2010, 16(2): 405-421.

[23] Christi MY. Airlift Bioreactors. In: R. D. Cook (ed.). Elsevier Applied Biotechnology Series, Springer, Berlin, Heidelberg, New York, 1989: 335-345.

[24] Su WW, Arias R. Continuous plant cell perfusion culture: bioreactor characterization and secreted enzyme production. Journal of Bioscience and Bioengineering. 2003, 95(1): 13-20.

[25] Mahmoudifar N, Doran PM. Tissue engineering of human cartilage and osteochondral composites using recirculation bioreactors. Biomaterials. 2005, 26(34): 7012-7024.

[26] Hu W, Zhong J. Effect of bottom clearance on performance of airlift bioreactor in high-density culture of Panax notoginseng cells. Journal of Bioscience and Bioengineering. 2001, 92(4): 389-392.

[27] Tang WL, Zhao H. Industrial biotechnology: tools and applications. Biotechnology Journal. 2009, 4(12): 1725-1739.

[28] Bancroft GN, Sikavitsas VI, Mikos AG. Design of a flow perfusion bioreactor system for bone tissueengineering applications. Tissue Engineering. 2003, 9(3): 549-554.

[29] Johnson DL, Koplik J, Schwartz LM. New pore-size parameter characterizing transport in porous media. Physical Review Letters. 1986, 57(20): 2564-2567.

[30] Shastri VP, Martin I, Langer R. Macroporous polymer foams by hydrocarbon templating. Proceedings of the National Academy of Sciences of the United States of America. 2000, 97(5): 1970-1975.

[31] Goskonda VR, Khan MA, Hutak CM, Reddy IK. Permeability characteristics of novel mydriatic agents using an in vitro cell culture model that utilizes SIRC rabbit corneal cells. Journal of Pharmaceutical Sciences. 1999, 88(2): 180-184.

[32] Darling EM, Athanasiou KA. Articular cartilage bioreactors and bioprocesses. Tissue Engineering. 2003, 9(1): 9-26.

[33] Zhang H, Williams-Dalson W, Keshavarz-Moore E, Shamlou PA. Computational-fluid-dynamics (CFD) analysis of mixing and gas-liquid mass transfer in shake flasks. Biotechnology and Applied Biochemistry. 2005, 41(Pt 1): 1-8.

[34] Bear J. Dynamics of Fluids in Porous Media. Dover Books on Physics and Chemistry, Dover Publication, New York, 1988: 5-20.

[35] Tropea C, Yarin AL, Foss JF. Springer handbook of experimental fluid mechanics. Vol. 1, Springer, Berlin, Heidelberg, New York, 2007: 56.

[36] KL Buehler. Effect of Membrane-Support and Solvent Quality on Permeability Characteristics of Confined Polyacrylamide Gels. PhD Thesis, Carnegie Mellon University Pittsburgh, PA USA, 1999, 70-90.

[37] Happel J, Brenner H. Low Reynolds Number Hydrodynamics: with special application to particulate media. In: Mechanics of Fluids and Transport Processes, Nartinus Jijhof Publisher, Dordrecht, Netherlands, 1965, 10-200.

[38] Wu J-, Yin S-. A Micro-Mechanism Model for Porous Media. Communications in Theoretical Physics. 2009, 52: 936-940.

[39] Ergun S. Fluid Flow through Packed Columns. Chemical Engineering Progress. 1952, 48(2): 89-94.

[40] Nagata S. Mixing-principle and applications, 3rd ed., John Wiley and Sons, Halstedt Press, New York, 1975, 138-144.

[41] Kuhbier JW, Weyand B, Radtke C, Vogt PM, Kasper C, Reimers K. Isolation, characterization, differentiation, and application of adipose-derived stem cells. Advances in Biochemical Engineering/Biotechnology. 2010, 123: 55-105. 
[42] McDuffe NG. Bioreactor Design Fundamentals, 3rd ed, Butterwood-Heinemann, Boston, 1991: 10-90.

[43] Israelowitz M, Rizvi S, Holmes C, Gille C, von Schroder HP. Apparatus for culture and growth of cells to a three-dimensional tissue, European Union Patent 200808011144.6/EP 2031501.

[44] Israelowitz M, Rizvi S, Holmes C, Gille C, von Schroder HP. Laminar Flow Bioreactor, United States Patent Application 20076083494/20090061508.

[45] Martin I, Wendt D, Heberer M. The role of bioreactors in tissue engineering. Trends in Biotechnology. 2004, 22(2): 80-86.

[46] Grayson WL, Bhumiratana S, Cannizzaro C, Vunjak-Novakovic G. Bioreactor cultivation of functional bone grafts. Methods in Molecular Biology. 2011, 698: 231-241.

[47] Weyand B, Israelowitz M, von Schroeder HP, Vogt PM. Fluid dynamics in bioreactor design: considerations for the theoretical and practical approach. Advances in Biochemical Engineering/Biotechnology. 2009, 112: 251-268.

[48] Johnson DL, Koplik J, Dashen R. Theory of dynamic permeability and tortuosity in fluid-saturated porous media. Journal of Fluid Mechanics. 1987, 176: 379-420.

[49] Voronov R, Vangordon S, Sikavitsas VI, Papavassiliou DV. Computational modeling of flow-induced shear stresses within 3D salt-leached porous scaffolds imaged via micro-CT. Journal of Biomechanics. 2010, 43(7): 1279-1286.

[50] Cioffi M, Boschetti F, Raimondi MT, Dubini G. Modeling evaluation of the fluid-dynamic microenvironment in tissue-engineered constructs: a micro-CT based model. Biotechnology and Bioengineering. 2006, 93(3): 500-510.

[51] Porter B, Zauel R, Stockman H, Guldberg R, Fyhrie D. 3-D computational modeling of media flow through scaffolds in a perfusion bioreactor. Journal of Biomechanics. 2005, 38(3): 543-549.

[52] Zhao F, Chella R, Ma T. Effects of shear stress on 3-D human mesenchymal stem cell construct development in a perfusion bioreactor system: Experiments and hydrodynamic modeling. Biotechnology and Bioengineering. 2007, 96(3): 584-595.

[53] Vossenberg P, Higuera GA, van Straten G, van Blitterswijk CA, van Boxtel AJ. Darcian permeability constant as indicator for shear stresses in regular scaffold systems for tissue engineering. Biomechanics and Modeling in Mechanobiology. 2009, 8(6): 499-507.

[54] Sandino C, Planell JA, Lacroix D. A finite element study of mechanical stimuli in scaffolds for bone tissue engineering. Journal of Biomechanics. 2008, 41(5): 1005-1014.

[55] Martin Y, Vermette P. Bioreactors for tissue mass culture: design, characterization, and recent advances. Biomaterials. 2005, 26(35): 7481-7503.

[56] Sikavitsas VI, Bancroft GN, Holtorf HL, Jansen JA, Mikos AG. Mineralized matrix deposition by marrow stromal osteoblasts in 3D perfusion culture increases with increasing fluid shear forces. Proceedings of the National Academy of Sciences of the United States of America. 2003, 100(25): 14683-14688.

[57] McCoy RJ, O'Brien FJ. Influence of shear stress in perfusion bioreactor cultures for the development of three-dimensional bone tissue constructs: a review. Tissue Engineering. Part B, Reviews. 2010, 16(6): 587-601.

[58] Weyand B, Reimers K. Vogt PM, Influences of extracellular matrix properties and flow shear stresses on stem cell shape in a three-dimensional dynamic environment. Conf Proc IFMBE Proc. 2011, 30: 47-50.

[59] Bianchi G, Harders M, Székely G. Mesh Topology Identification for Mass-Spring Models. In: R. E. Ellis, T. M. Peters (eds.). Medical Image Computing and Computer-Assisted Intervention MICCAI 2003. Lecture Notes in Computer Science, Springer, Berlin, Heidelberg, New York, 2003: 50-58.

[60] Ferzinger JH. Computational Methods for Fluid Dynamics. 3rd edition, Springer, Berlin, Heidelberg, New York, 2001: 265-306.

[61] Shuib AS, Hoskins PR, Easson WJ. Flow Regime Characterization in a diseased artery model. Proceedings of World Academy of Science, Engineering and Technology. 2010, 62: 110-114. 
[62] Sanz-Herrera JA, Kasper C, van Griensven M, Garcia-Aznar JM, Ochoa I, Doblare M. Mechanical and flow characterization of Sponceram carriers: Evaluation by homogenization theory and experimental validation. Journal of Biomedical Materials Research. Part B, Applied Biomaterials. 2008, 87(1): 42-48.

[63] Smith SD, Sachs L. Difference in the Cell proliferation and colony-forming ability of normal human T lymphocytes. Clinical Immunol Experimental. 1979, 37: 348-351.

[64] Smith SD, Wood GW, Fried P, Lownan J T. In vitro growth of lymphoma colonies from children with Non-Hodgkin's lymphoma. Cancer. 1981, 48: 2612-2623.

[65] Mancuso L, Liuzzo MI, Fadda S, Pisu M, Concas A, Cincotti A, Cao G. In vitro ovine articular chondrocyte proliferation: experiments and modelling. Cell. 2010, 42: 310-320. 


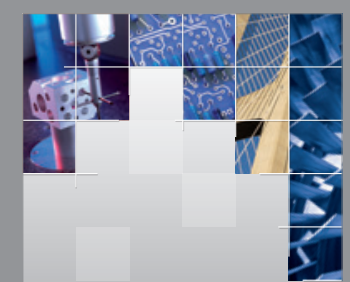

\section{Enfincering}
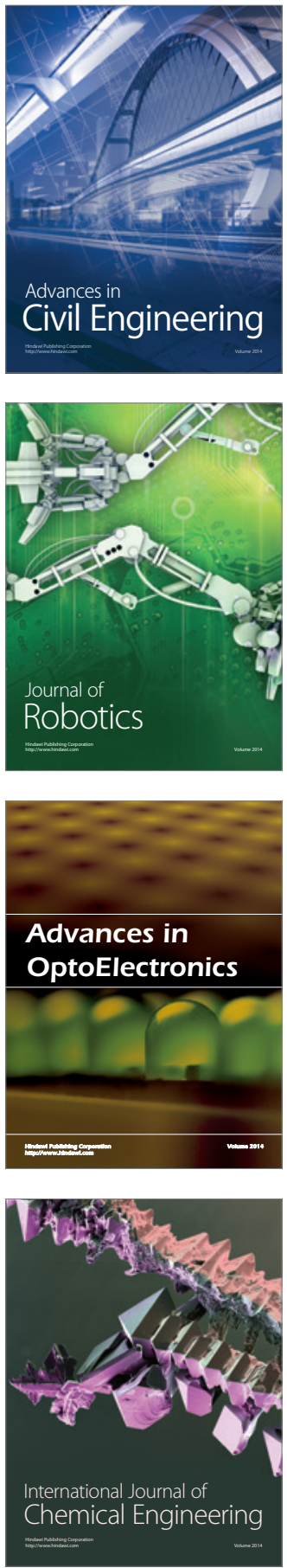

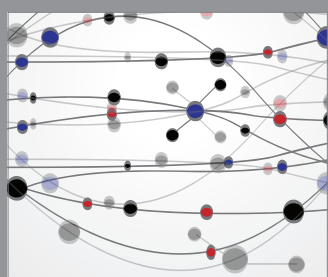

The Scientific World Journal

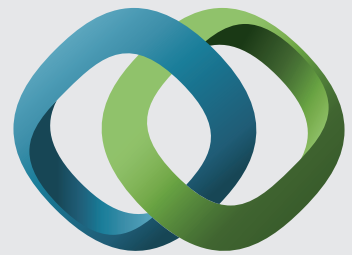

\section{Hindawi}

Submit your manuscripts at

http://www.hindawi.com
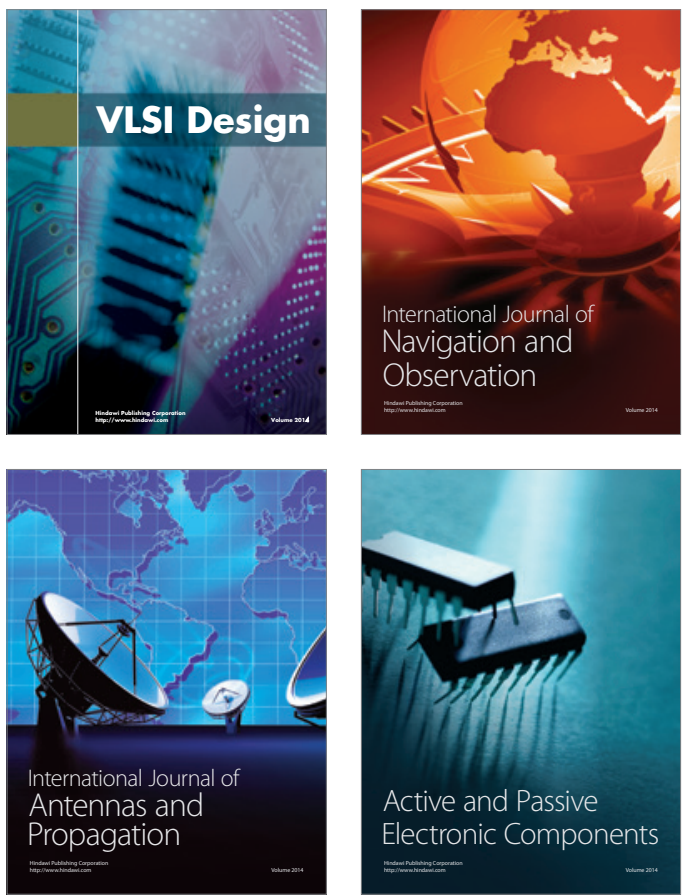
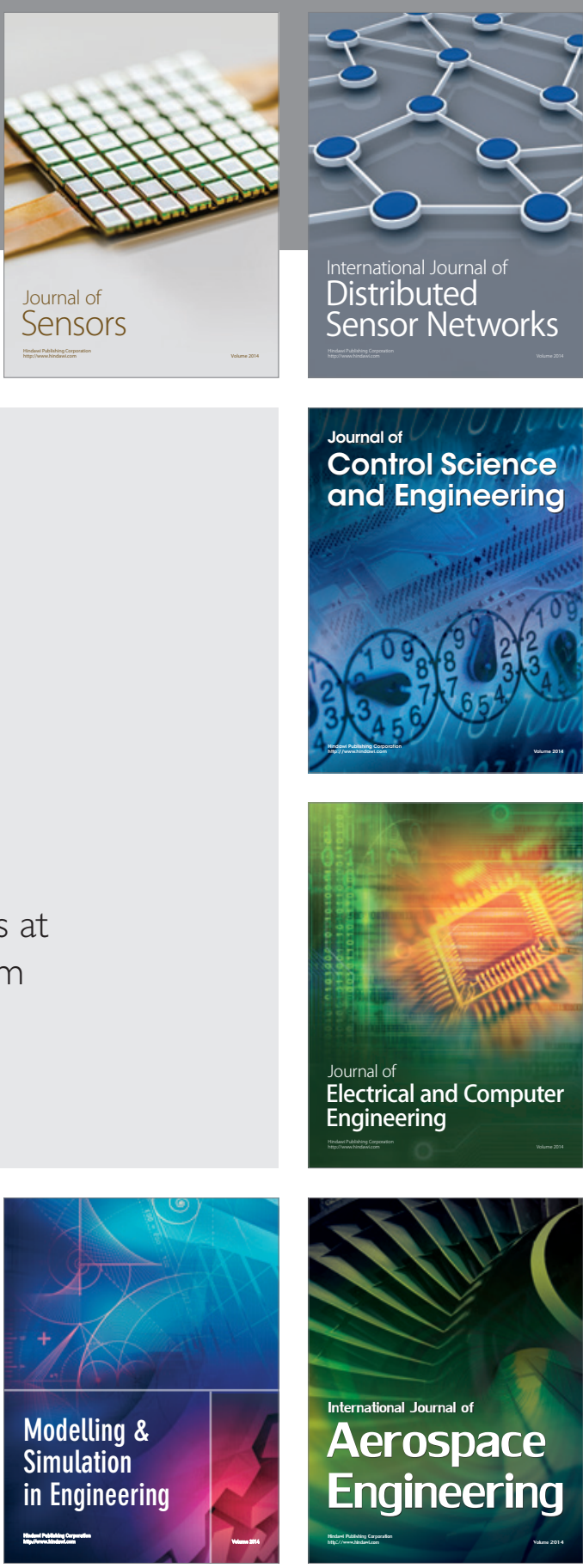

International Journal of

Distributed

Sensor Networks

Journal of

Control Science

and Engineering
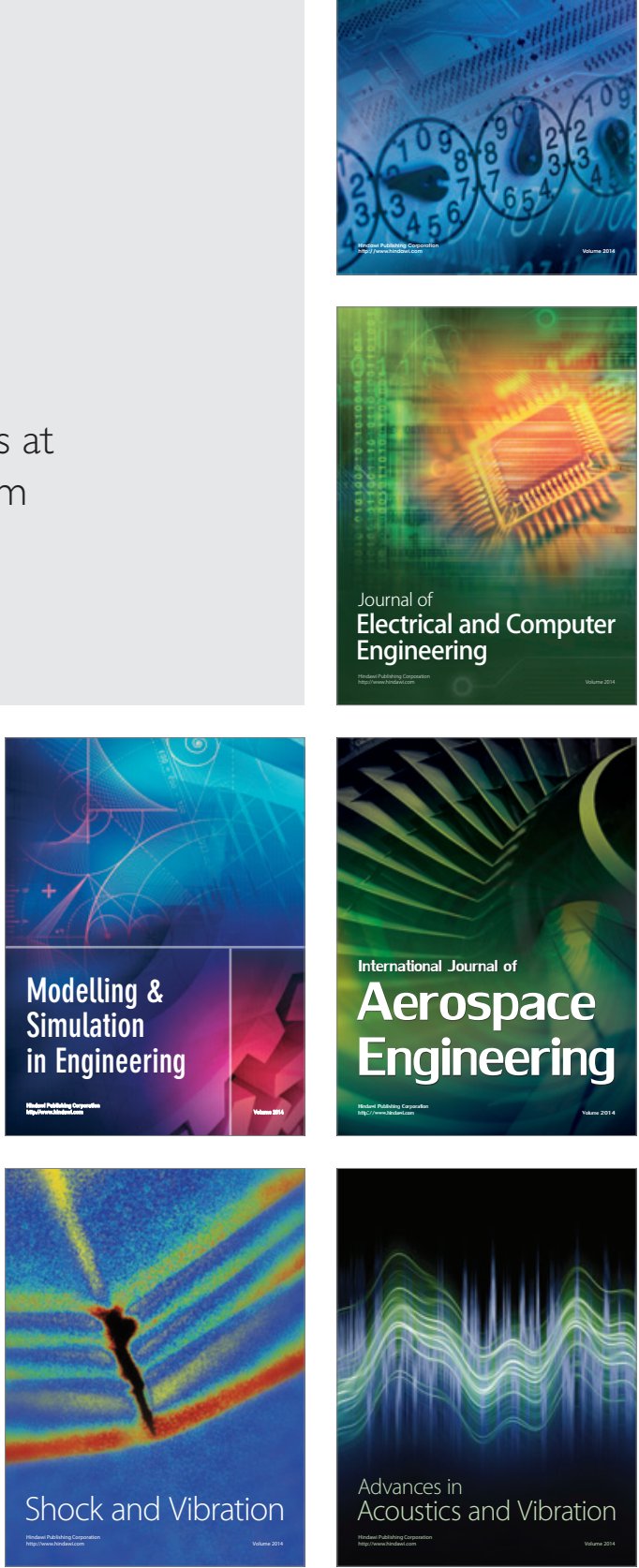